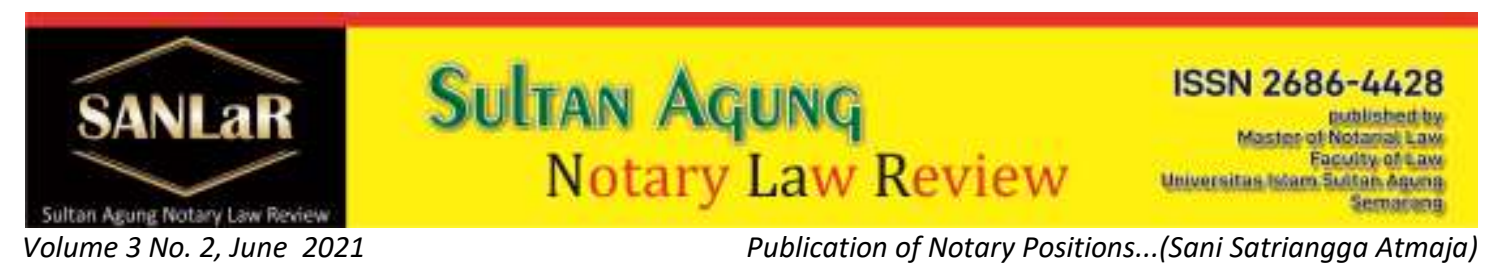

\title{
Publication of Notary Positions on Personal Social Media Accounts
}

\author{
Sani Satriangga Atmaja*) \\ *) Faculty of Law, Universitas Islam Sultan Agung (UNISSULA) Semarang, E-mail: \\ satrianggasani@gmail.com
}

\begin{abstract}
A notary is a public official who is authorized to make an authentic deed with perfect evidentiary power. The position of a Notary is a Public Position that upholds the dignity and trust of the community so that in carrying out its duties, it must adhere to the prevailing laws and regulations and the Code of Professional Ethics. Based on the provisions of the Professional Code of Ethics, a Notary is prohibited from publishing his position or self-promotion, while in this digital era it is not uncommon for a Notary to list his position on his social media accounts. The purpose of this study is to explain and analyze the legal consequences of the publication of a notary position and how to apply sanctions and solutions for violations of the code of ethics according to Act No. 2 of 2014 concerning the position of notary and the code of ethics of a notary. The method used in this study is the normative juridical method, the specifications in this study are descriptive analytical, the data used are secondary data, using data collection sourced from library research that produces primary law materials, secondary law materials, and tertiary law materials, problems analyzed with the theory of Triadism Law and the theory of Legal Effectiveness. The results of this study indicate that the prohibition on the publication of Notary Positions for Notaries is based on the fact that a Notary as a position that provides services to the public requires the trust of the public, thus Notaries are obliged to uphold their nobility of dignity in accordance with the Law on Notary Positions and the Notary Code of Ethics. The legal consequences for a Notary who publish his Notary Position in Social Media accounts are not in accordance with the oath / promise of Position that has been uttered and mandated by the Notary Position Act, and violates the prohibition provisions in the Notary Code of Ethics.
\end{abstract}

Keywords: Notary; Publication, Social Media; Sanctions.

\section{Introduction}

Notary is a position that carries out as a public function of the State in the field of Private Law and carries out a role in making an Authentic Deed that has the Power of Perfect Evidence ${ }^{1}$. Notary in carrying out his position must be bound by the provisions of the position regulated in UUJN. The Notary Position is a Trust Position, therefore a

\footnotetext{
1 The Use of the Notary Protocol That Is Stored Digitally as Evidence in the Court, Putri Isna Vonna, Yanis Rinaldi, Teuku Muttaqin Mansur, International Journal of Multicultural and Multireligious Understanding Vol 8, No 3 (2021), https://ijmmu.com/index.php/ijmmu/article/view/2507
} 
Notary must have good behavior based on the Position Act and Code of Ethics ${ }^{2}$. The Notary Code of Ethics basically contains regulations regarding the following matters:

1. Notary ethics in carrying out their duties;

2. Notary Professional Obligations;

3. Ethics regarding the relationship of a Notary with his client;

4. Ethics regarding relations with fellow Notaries; and

5. Prohibitions for Notaries. ${ }^{3}$

The reality in practice is that there are notaries who carry out a kind of "publication" whose function is to provide information or convince actual or potential consumers about the usefulness of a product or service (certain) with the aim of encouraging consumers to either continue or start purchasing the company's products or services at a price (certain) ${ }^{4}$. Notaries in carrying out their profession in providing services to the community should act according to the applicable rules. This is important because the Notary carries out the duties of his position not solely for personal interests, but also for the benefit of the community, and has an obligation to guarantee the truth of the Deeds he has made, therefore a Notary is required to be more sensitive, honest, fair and transparent in his actions. Deed to guarantee all parties directly involved in making an Authentic Deed. A Notary must adhere to the Code of Ethics for the Notary Position, because without it the dignity of Professionalism will be lost and will no longer be trusted by the public. ${ }^{5}$

Social Media has 4 (four) characteristics or characteristics, including the following:

\section{User Participation}

All Social Media encourages its users to participate and provide feedback on a message or content on Social Media. Messages sent can be received or read by many people;

There is openness

Most social media provide opportunities for users to comment, vote, share, and so on. Sending messages can be done freely without having to go through the Gatekeeper;

There's a Conversation

\footnotetext{
${ }^{2}$ Abdul Ghofur Anshori, 2009, Lembaga Kenotariatan Indonesia, Perspektif Hukum dan Etika, Yogtakarta, UII Press, p. 25.

${ }^{3}$ Munir Fuady, 2002, Perbuatan Melawan Hukum Pendekatan Kontemporer. Bandung, Citra Aditya Bakti, p. 36.

${ }^{4}$ Komaruddin Sastradipoera, 2003, Manajemen Marketing Suatu Pendekatan Ramuan Marketing. Bandung, Kappa Sigma, p. 31.

${ }^{5}$ Ibid, p. 55.
} 
Most social media allow interaction with content, be it in the form of reactions or conversations between users. And the recipient of the message is free to determine when to interact with the message; and

\section{Connectedness}

Through Social Media, its users can connect with other users through links and other sources of information. The process of sending messages to Social Media which is faster than other media makes a lot of information connected in one Social Media.

Social Media is a tangible form of social change in society as one of the impacts of globalization. Social Media has become something that is mandatory for most of the people. The role and function of Social Media in this case requires its users to be more open to the public. Even though it is open, as a State of Law, of course there are certain limitations for its users, such as for Notaries. As a public official, of course, notaries also use social media applications a lot. The Notary has taken the Oath of Position in accordance with the UUJN and promised to comply with the Code of Ethics. The organization must of course use Social Media wisely considering that the Code of Ethics prohibits a Notary from publishing his position.

\section{Research Methods}

The writing of this thesis uses an analytical method with a normative juridical approach, which is a study that seeks to synchronize the applicable legal provisions in the legal protection of norms or other legal regulations with their relation to the application of these legal regulations in actual practice in the field. ${ }^{6}$ This research uses descriptive analytical research specifications, which describe the applicable laws and regulations associated with legal theories and the practice of implementing positive law regarding these problems. ${ }^{7}$

\section{Results and Discussion}

\subsection{Legal Consequences of Publication of Notary Positions through Social Media Accounts}

The provisions on the prohibition of publication of the Notary Position are regulated in Article 4 point 3 of the Notary Code of Ethics which states that Notaries and other people who hold and carry out the Notary Office are prohibited from publishing or promoting themselves, either alone or jointly, by including their Name and Position, using Print Media and / or electronically in the form of: a.) Advertisements; b.) congratulations; c.) condolences; d.) thanks; e.) marketing activities; f.) sponsorship

\footnotetext{
6Soerjono Soekanto dan Sri Mamudji, 1985, "PenelitianHukum Normatif Suatu Tinjauan Singkat", Jakarta: Penerbit Rajawali Pers, p. 52

${ }^{7}$ Bambang Sunggono, 2001, "Metode PenelitianHukum, Ed. III, Jakarta: Penerbit Raja Grafindo Persada, p. 36
} 
activities, both in the social, religious, and sports fields;."

As for the exceptions relating to the publication of the Notary Position as regulated in Article 5 of the Code of Ethics, the exceptions are: a.) Congratulations, condolences by using greeting cards, letters, bouquets or other media by not including the Notary but only the name; b.) Posting of the name and address of the Notary in the official book by PT Telkom and/or other official agencies and/or institutions; c.) Install 1 (one) road sign with a size not exceeding $20 \mathrm{~cm} \times 50 \mathrm{~cm}$, white base, black letters, without including the Notary's Name and installed within a maximum radius of 100 meters from the Notary's office.

\subsection{Application of Sanctions and Solutions for Violations of the Notary Code of Ethics}

Sanctions ${ }^{8}$ for Notaries are contained in the UUJN and the Notary Code of Ethics. The sanctions contained in the UUJN are listed in articles 84-85. In Article 84 it is stated that if the Notary violates (does not carry out) the provisions as referred to in Article 16 paragraph (1) letter i, Article 16 paragraph (1) letter k, Article 41, Article 44, Article 48, Article 49, Article 50, Article 51, Article 52, the deed made by a notary only has the power of proof as an underhand deed or the deed becomes null and void by law. Whereas in Article 85, if the Notary violates the provisions of Article 27, Article 32, Article 37, Article 54, Article 58, Article 59 and/or Article 63, the Notary will be subject to sanctions in the form of:
a. verbal reprimand;
b. written warning;
c. Temporary suspension;
d. Dismissal with honor; and
e. Dismissal with no respect.

While other ethical-related sanctions, there are: in Article 6 number 1 of the Notary Code of Ethics. Sanctions imposed on members who violate the Code of Ethics can be in the form of:
a. rebuke;
b. Warning;
c. Schorsing (temporary dismissal) from membership of the association;

\footnotetext{
8 Njoto, M. 2019. Sanksi Bagi Notaris Yang Mempromosikan Jabatannya Pada Sosial Media. Jurnal Panorama Hukum, 4(1), 31-41. https://doi.org/10.21067/jph.v4i1.3885
} 
d. Onzetting (dismissal) from membership of the association;

e. Disrespectful dismissal from association membership.

In Article 6 point 2 it is stated that the imposition of sanctions as described in number 1 against members who violate the Code of Ethics is adjusted to the quantity and quality of violations committed by the member. The Honorary Council is a tool for associations authorized to carry out examinations for violations of: Code of Ethics and impose sanctions on violators according to their respective powers.

As stated in Article 6 point 2 that the imposition of sanctions adjusted to the quantity and quality of the violation feels very odd. This is because there is no clear limit on which actions can be subject to these sanctions. As a sanction, the mechanism and procedure must be clear in order to achieve the principles of justice and certainty.

Publications made by a Notary are also not clear what kind of sanctions should be imposed. It solely depends on the judgment of the Honorary Council. The forms of violations and sanctions in the Code of Ethics should be divided into 3 categories as is a form of categorizing violations and legal sanctions in general. The categories are light, medium, and heavy. If a Notary carries out a persuasive promotion, it should be subject to severe sanctions, because the sentence with a persuasive tone seems to really hope / request the willingness of people to come and take care of the Deed at the Notary concerned.

Meanwhile, supervision over the implementation of the code of ethics is carried out by:

1. At the first level by the Regional Board of the Indonesian Notary Association and the Regional Honorary Council;

2. At the level of appeal by the Regional Board of the Indonesian Notary Association and the Regional Honorary Council;

3. At the final level by the Central Board of the Notary Association. Indonesia and the Central Honorary Council.

Decisions made by the Regional Honorary Council, Regional Honorary Council as well as those determined by the Central Honorary Council are carried out by the Regional Management. Regional Managers are required to record in the Association member books that are in the Regional Management for every decision that has been made by the Regional Honorary Council, Regional Honorary Council and/or Central Honorary Council regarding the case of the Code of Ethics along with the name of the member concerned. Furthermore, the name of the Notary, cases and decisions of the Regional Honorary Council, Regional Honorary Council and/or Central Honorary Council are announced in the Notary Media which is published after recording in the books of the Association members.

The purpose of the series of actions is of course to create an effect of shame on the 
Notary so that he is deterred and will not repeat the actions/actions that violate the Code of Ethics. It is also necessary for other Notaries not to participate in violating the Code of Ethics so that efforts to enforce the Code of Ethics can be carried out. And of course, with strict sanctions, the public will positively evaluate the efforts of the Honorary Council to take firm action against members of the Notary Public who violate the Code of Ethics, so that public trust in the Notary Profession grows.

Along with the times followed by advances in information and communication technology, the Notary Code of Ethics should also pay attention to the developments of the times, such as related to how policies for Notaries use Social Media, especially regarding the publication of Notary Positions.

\section{Closing}

\subsection{Conclusion}

The existence of a prohibition on the publication of a Notary Position for a Notary is based on the fact that a Notary as a position that provides services to the public requires the trust of the community it serves, and the existence of a Notary is not for the personal interest of the person appointed, so that the Notary is obliged to uphold his nobility in accordance with the law of Notary Position and Notary Code of Ethics. Legal consequences for a Notary who publishes his Notary Position in a Social Media account that does not match the oath / promise of Position that has been uttered and mandated by the Notary Position Act, and violates the prohibition provisions in the Notary Code of Ethics; and it is important for a Notary who violates the Notary Position Act and the provisions of the Notary Code of Ethics to be sanctioned as a form of awareness that the Notary in carrying out his position has violated the provisions of the Notary Position Act and the Notary Code of Ethics as well as to protect consumers and maintain the good name of the Notary Profession. Sanctions in the Notary Position Act and the Minister of Law and Human Rights Regulation Number 15 of 2020 and the Notary Code of Ethics are contained in article 6 of the Code of Ethics, namely in the form of: reprimand, warning, schorsing, onzetting and dishonorable discharge from association membership. Appeals and submissions / applications at the final level are only intended for Notaries who are subject to suspension and onzetting sanctions.

\subsection{Suggestion}

It is necessary to update the provisions of the Notary Code of Ethics which are no longer in accordance with the times, science, technology, and the Industrial Revolution 4.0, especially regarding the publication of Positions through Social Media for Notaries; and there is a need for strict and binding sanctions by the Notary Honorary Board as the bearer of the mandate to enforce the Notary Code of Ethics and it is necessary to update the sanctions settings in the Code of Ethics, and carry out firmly without any discrimination between 1 (one) Notary and another Notary. The regulation is expected 
to be more detailed so that objectivity arises in implementing the principle of legal certainty to avoid subjectivity in imposing sanctions by the Notary Honorary Council.

\section{References}

Journals:

[1] Njoto, M. 2019. Sanksi Bagi Notaris Yang Mempromosikan Jabatannya Pada Sosial Media. Jurnal Panorama Hukum, 4(1), 31-41. https://doi.org/10.21067/jph.v4i1.3885

[2] The Use of the Notary Protocol That Is Stored Digitally as Evidence in the Court, Putri Isna Vonna, Yanis Rinaldi, Teuku Muttaqin Mansur, International Journal of Multicultural and Multireligious Understanding Vol 8, No 3 (2021), https://ijmmu.com/index.php/ijmmu/article/view/2507

Books:

[1] Abdul Ghofur Anshori, 2009, Lembaga Kenotariatan Indonesia, Perspektif Hukum dan Etika, Yogtakarta, UII Press

[2] Bambang Sunggono, 2001, "Metode PenelitianHukum, Ed. III, Jakarta: Penerbit Raja Grafindo Persada

[3] Komaruddin Sastradipoera, 2003, Manajemen Marketing Suatu Pendekatan Ramuan Marketing. Bandung, Kappa Sigma

[4] Munir Fuady, 2002, Perbuatan Melawan Hukum Pendekatan Kontemporer. Bandung, Citra Aditya Bakti

[5] Soerjono Soekanto dan Sri Mamudji, 1985, "PenelitianHukum Normatif Suatu Tinjauan Singkat", Jakarta: Penerbit Rajawali Pers 